\title{
DESCRIPTION OF THE TETRA 1 TECHNOLOGY AND STANDARD FOR MODERN DIGITAL TRUNKING SYSTEMS OF FUNCTIONAL MOBILE RADIO COMMUNICATIONS
}

\author{
Slađan M. Svrzića ${ }^{\text {, Petar Jovanoski }}{ }^{\mathrm{b}}$ \\ a Tesla Systems Ltd, Belgrade, Republic of Serbia, \\ e-mail: milosavljevic_svrzic@hotmail.com, corresponding author, \\ ORCID iD: (Dhttps://orcid.org/0000-0003-4525-9844 \\ ${ }^{\mathrm{b}}$ EVN Macedonia, Skopje, Republic of North Macedonia, \\ e-mail: jovanoski55@yahoo.com
}

DOI: 10.5937/vojtehg69-30858; https://doi.org/10.5937/vojtehg69-30858

FIELD: Telecommunications

ARTICLE TYPE: Review paper

\begin{abstract}
:
Introduction/purpose: Since the end of 1995, when TETRA MoU promoted the new TETRA Standard within ETSI, tentatively called TETRA 1, it quickly began to be used, almost exclusively, for the construction of Functional UHF digital trunking systems for mobile radio communications.

Methods: A description of the relevant issues from the TETRA 1 technology standards and an analysis of existing specifications, with a more detailed presentation of the radio interface.

Results: This article highlights the numerous advantages that radio systems based on the TETRA Standard have in relation to the Functional systems of analog trunking of mobile radio communications, and gives an overview of the basic package of Specifications for system implementation based on the TETRA Standard 1. It describes the interfaces used in the system with a special reference to the description of the radio interface, organized by TDMA, and the method of integration of voice and data transmission. The organization and the basic elements of the TETRA network infrastructure are presented as well as those of the final user's equipment, followed by the analysis of possible practical architectures of mobile radio communication networks based on that standard.
\end{abstract}

Conclusion: After the general descriptions of technology, organization, and architecture, the following are presented: the basic concept of the organization of TETRA 1 network use, the general principle of organization of mobile participants' connections and the basic elements of the TETRA 
network as well as the architecture and topology of the TETRA 1 network construction.

Key words: Mobile radio communications-MR, Professional Mobile Radio Communication System-PMR, analog trunking, digital trunking, TDMA, Radio-Air interface, Digital Trunking System of Mobile Radio Communications-TETRA, ETSI.

\section{Introduction}

The beginnings of TETRA (TErrestrial Trunked RAdio) date back to 1989, when four leading European companies for the production of mobile radio equipment (Ericsson, Motorola Solutions, Nokia, and Philips) began work on developing a system of mobile digital trunking radio communications for integrated speech and data transmission, called the MDTRS (Mobile Digital Trunked Radio System). During the same year, work began in North America on the development of a new, accompanying Standard for Interoperable Digital Mobile Radio Communications for Voice Transmission, today known as P25 (Project 25). While the development of the P25 Standard was the responsibility of the North American Public-Safety Community (NAPsC), TETRA was developed under the auspices of the European Telecommunications Standards Institute (ETSI), supported by many manufacturers and equipment vendors, system users and regulators (Ovchinnikov et al, 2000), (Svrzić \& Ćosović, 2002a, 2002b), (Swan, 2015), (Svrzić, 2021).

As the interest of manufacturers of equipment of Functional Mobile Radio Communications Systems-PMR (Professional Mobile Radio) for the new standard progressed by providing significant support during 1993, the way was paved for the emergence of a strong and solidary association of manufacturers and sellers of such equipment. Therefore, in December 1994, under the auspices of ETSI, the TETRA MoU Association (TETRA Memorandum of Understanding) was formed and started working, uniting the world's most important manufacturers and sellers of PMR equipment at the time. As such, the TETRA MoU association has played a very important role from the very beginning (until today), not only for the permanent development of TETRA but also for maintaining interoperability, creating new market opportunities, and fighting against fierce competition (Ovchinnikov et al, 2000), (Swan, 2015), (Svrzić, 2021). By the end of May 1999, the TETRA MoU Association already consisted of 58 different organizations from 18 countries around the world (out of which: 23 equipment manufacturers, 12 system and operator owners, 3 regulatory bodies, etc.) (Dunlop et al, 1999). 
In August 1995, ETSI adopted and approved the Specification ETS 300391 (Part 1, 2 and 3), within which the general settings for the security architecture of the UPT system (Universal Personal Telecommunication) were defined, the ICS proforma (Implementation Conformance Statement proformas) was given as well as certain CTSs (Conformance Test Specifications) (ETSI, 1995). Subsequently, in December of the same year, ETSI adopted and approved the new TETRA Radio Interface-TAI (TETRA Air Interface), as the full European Telecommunications Standard (ETS) EN 300 392-Part 2, although TETRA was already aiming ambitiously not only at the European, but also at the the complete world market (ETSI, 1996). The new standard, tentatively named TETRA 1 , was not related to the then existing Public Access Mobile Radio Access System (PAMR), nor was the PAMR part of TETRA, as TETRA proved to be an adaptable standard for Functional Mobile Radio Communication Systems. Namely, the infrastructure of the TETRA system is formed from switching elements, a certain number of base and many mobile radio stations, and, being a highly redundant and flexible system for all requirements, it seems ideal both for regular business and functional mobile radio communications and for mobile radio communications in critical situations for general public safety. The TETRA 1 standard is a set of necessary Specifications (recommendations) for integrated voice and data transmission-TETRA V+D (TETRA Voice + Data) and within that for group, broadband, and emergency calls, then for fast access to the system (which is usually shorter than $300 \mathrm{~ms}$ ), for TMO (Trunking Mode Operation) and DMO type of work (Direct Mode Operation), for different levels of application of system access protection through authentication and information encryption, for telephony with network participants functional PABX and participants of public PSTN (including full duplex), to support the smooth operation of control points (Control and Dispatch Centers), and circuit-switched data transmission, as well as for independent packet data transmission by TETRA PDO (TETRA Packet Data Optimized). (Ovchinnikov et al, 2000), (Swan, 2015), (Svrzić, 2021)

Although at the time of the creation of the TETRA 1 Standard, the data transfer rate (Data) in it was relatively low and comparable to the data transfer rate of other technologies, it should be noted that even at that time the TETRA 1 Standard offered a powerful system of Status Messages-SM and short written messages-SDM (Status and Short Data Messaging), as well as a special data package directly related to the execution of special tasks in the field. However, fewer than five years 
passed since its inception when members of the ETSI TETRA project, which includes both users and equipment manufacturers, within the TETRA Technical Committee (TC) and the TETRA Association (TA), in 1999, recognized the need for necessary improvements of the first generation of the existing standard, tentatively called the TETRA 1 Standard, in several different areas. Although the number of these areas was initially wide, significant developments in the telecommunications industry (combined with changes in market needs) led to ETSI deciding in September 2000 to start activities to improve the existing standard towards second-generation TETRA (Swan, 2015), (Svrzić, 2021). As a result of these activities, at the end of 2005, a document was published defining the areas, services and characteristics of the TETRA 1 Standard, which were envisaged for treatment and improvements through the planned new TETRA 2 Standard, as follows:

- Increase connection range in the TMO mode.

- Use of a multi-purpose adaptive voice codec- AMR (Adaptive Multiple Rate).

- Use of mixed excitation, with line prediction, excited voice codec MELPe (Mix Exitation Line Prediction).

- Introduction of an improved part of the standard for fast data transfer, called TEDS (TETRA Enhanced Data Service) (Swan, 2015), (Nouri, 2016), (Svrzić, 2021).

In particular, it should be noted that the development of high-speed data transfer according to the TETRA 2 Standard, i.e. the introduction of part of the standard for high-speed data transmission according to TEDS, had its prehistory since at the beginning there were two different ways of its development:

1.- TETRA Advancet Packet Service - TAPS, which was based on the evolution of the GRPS / EDGE standard, and was thus focused mainly on the PAMR market, i.e. for public mobile communications.

2.- TETRA Enhanced Data Service - TEDS, which implied a slightly different appearance of the standard in terms of data transfer speed, and was aimed at the entire TETRA market (in all sectors). In addition, it envisaged full compatibility with TETRA $1 \mathrm{~V}+\mathrm{D}$ and easy migration of equipment from TETRA $1 \mathrm{~V}+\mathrm{D}$ to TEDS, as well as flexible use of the existing frequency spectrum allocated for use in PMR of different holders.

At the end of that "race", and after the consensus reached at the working group WG4 EPT on 04.07.2002, the concept of TEDS won as a direction preferred by a group of the world's 5 largest manufacturers of 
TETRA equipment (with six different technologies) and most of the functional users of PMR. However, due to the painstaking debate over the choice of only one, since then initially offered technology options, there were many failed attempts to reach a consensus on this issue as well. The most important thing is that after 4 years of controversy, the decision was finally made, so the amended TETRA 2 Standard was finally made public in 2006. Since then, until today, several significant improvements have been made within the new TETRA 2 Standard, including the previously mentioned: High Speed Data (HSD) and the selection and standardization of additional voice codecs for speech digitization. In addition, the following were realized: the evolution of the TETRA SIM card, achieving interoperability (even "roaming"), between TETRA 2 and public GSM, as well as the transition from $2.5 \mathrm{G}$ to $3 \mathrm{G}$ network, while maintaining wide compatibility with the first generation of TETRA 1 devices and full integration of their features into the new generation of TETRA 2 devices. (Swan, 2015), (Nouri, 2016), (Svrzić, 2021)

When it comes to the availability and harmonization of the frequency spectrum, i.e. spectral efficiency, it should be pointed out that these were the key moments for the worldwide success of the TETRA Standard. Namely, an open MR (Mobile Radio) standard, which means that equipment from different manufacturers can be used in a single radio network, must offer the system owner (on the one hand) sufficient spectral efficiency, with the possibility of choosing equipment from different manufacturers, and at the same time it must enable the manufacturer (on the other hand) to achieve reasonable economy on the existing scale, in order to maintain itself in the widely competitive world market of sellers. Thanks to the work of the European Radiocommunications Office (ERO) from the Community European Conferences of Postal and Telecommunications Administrations (CEPT), and consultations with NATO and their substantial cooperation (as well as the cooperation of some other users of the radio spectrum in Europe), for the needs of the TETRA system in Europe, subbands of frequencies have been defined:

- $380-385$ and $390-395 \mathrm{MHz}$, which is 200 communication radio channels with a width of $25 \mathrm{kHz}$ (strictly for the needs of public security and safety services and the army),

- 410-430 and 450-470 MHz, which is additional 800 communication radio channels $25 \mathrm{kHz}$ wide (intended for the needs of commercial services: services, transport, etc.), and 
- 870-876 and 915-921 MHz, which is more additional 240 communication radio channels with a width of $25 \mathrm{kHz}$ (also intended for the needs of commercial services: services, transport, etc.).

Also, the mentioned $380-400 \mathrm{MHz}$ and $410-430 \mathrm{MHz}$ parts of the spectrum, otherwise designated as basic subbands, together with the newly assigned auxiliary subband $806-870 \mathrm{MHz}$, are also widely available for use by TETRA in other regions of the world (meaning those outside Europe: in America, Asia, Australia, etc.). (Ovchinnikov et al, 2000), (Swan, 2015), (Svrzić \& Ćosović, 2002a, 2002b), (Svrzić, 2021)

Initially, there were concerns about whether this radio spectrum width would be sufficient for the frequency plan, as well as whether it would allow the required density of TETRA network elements, necessary for good radio coverage and adjusted capacity of communication radio channels, to be implemented. However, the improved technical RF (Radio Frequency) characteristics in the standard have allowed the third generation mobile TETRA terminals to operate successfully on the combined broadband configuration of both basic subbands, i.e. in the continuity of 380 to $430 \mathrm{MHz}$. This made it possible, by combining the basic spectral subbands of $380-400 \mathrm{MHz}$ and $410-430 \mathrm{MHz}$, to provide additional radio coverage and increased capacity of communication radio channels wherever necessary (of course, if the user has that spectrum width available). That is why TETRA has already unequivocally proved its pronounced spectral efficiency in that respect, since from the very beginning it has enabled a large number of today's operating national networks to be able to function simultaneously and successfully only in the basic part of the spectrum from 380 to $400 \mathrm{MHz}$, i.e. without the use of additional sub-bands of the radio spectrum. (Swan, 2015), (Svrzić, 2021)

\section{Advantages of digital standards and technologies for PMR trunking systems}

Mobile radio communication trunking systems, both analog and digital, are in fact UHF (Ultra High Frequency) mobile radio communication systems that automatically switch the available communication radio channels of Base Radio Stations (BRSt) for the interconnection of mobile participants as well as for the connection of mobile participants with other participants. One of these communication radio channels must be used as a Control Channel. Through this channel, calls are registered by mobile and other participants, status messages are 
transmitted and the order of connection requests is assigned. Namely, as soon as the request for establishing a connection arrives, one of free communication radio channels (channels from the capacity of the respective BRSt, in whose service zone the participant who sent the connection request is assigned) is assigned to the participants for exclusive use to occupy that channel for communication with each other. In cases when, during the established connection, new calls for establishing connections via the same BRSt arrive on the system, they are assigned the remaining ones and not the occupied communication radio channels for the connection, until the full utilization of the communication radio channels on the respective BRSt. If all channels are busy, a queue is formed for new connection requests (these requests are queued). As soon as one of the busy communication radio channels is vacated, the system assigns it to the first participant from the formed waiting list. This means that in the trunking system of mobile radio communications, the call for connection is sent only once because, in case of impossibility for current connection, the call will be placed on the waiting list and will be processed later in the order and priority that the participant has (Ovchinnikov et al, 2000), (Svrzić \& Ćosović, 2000), (Svrzić \& Ćosović, 2002b). An important difference in the functioning of conventional from trunking systems of mobile radio communications is plastically shown in Figure 1.

Trunking Mobile radio communication systems belong to the class of mobile radio communication systems primarily oriented towards the formation of various functional and corporate radio networks which provide for the active application of mobile users in separate speech groups, formed for a permanent or temporary task. Such systems are used mainly by the police, specialized social security and protection services, companies engaged in land and air transport, large producers and distributors of all types of energy (oil, gas, electricity, etc.) in different countries, as well as by the military in order to provide functional connections between: mobile radio participants with each other, mobile radio participants and stationary radio participants, as well as between mobile radio participants and participants of Public telephone networksPSTN and ISDN, and Functional telephone networks-PABX. For Public and Functional trunking systems of mobile radio communications, there are a number of different standards differing from each other in: applied methods for transmission of voice signals (analog and digital); types of network access: FDMA (Frequency Division Multiplex Access), TDMA (Time Division Multiplex Access) and CDMA (Code Division Multiplex 
Access); the manner of allocating and determining the communication radio channel: with decentralized and centralized management; the type of Control-Management Channel: separated and distributed; and in other characteristics.

(Fiksno korišč enje saobraćajnih radio-kanala)

CONVENTIONAL SYSTEM OF MOBILE RADIO

COMMUNICATIONS

(Fixed use of traffic radio channels)
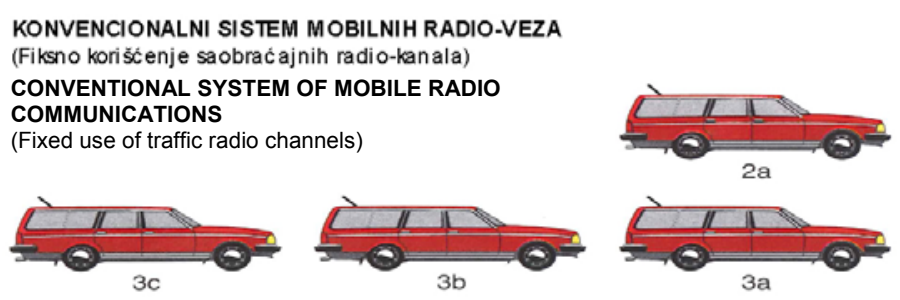

Kanal $\mathrm{N}^{\circ} 1$

Channel $\mathrm{N}^{\circ} 1$

Kanal $\mathrm{N}^{\circ} 2$

Channel $\mathrm{N}^{\circ} 2$

Kanal $\mathrm{N}^{\circ} 3$

Channel $\mathrm{N}^{\circ} 3$

Participants $3 \mathrm{~b}$ and $3 \mathrm{c}$ must wait until the occupied radio channel 3 is released

Kanal $\mathrm{N}^{\circ} 4$

Channel $\mathrm{N}^{\circ} 4$

Učesnici 3b i 3c moraju da sačekaju dok se ne oslobodi zauzeti radio-kanal 3

Kanal $N^{\circ} 5$

Channel $\mathrm{N}^{\circ} 5$

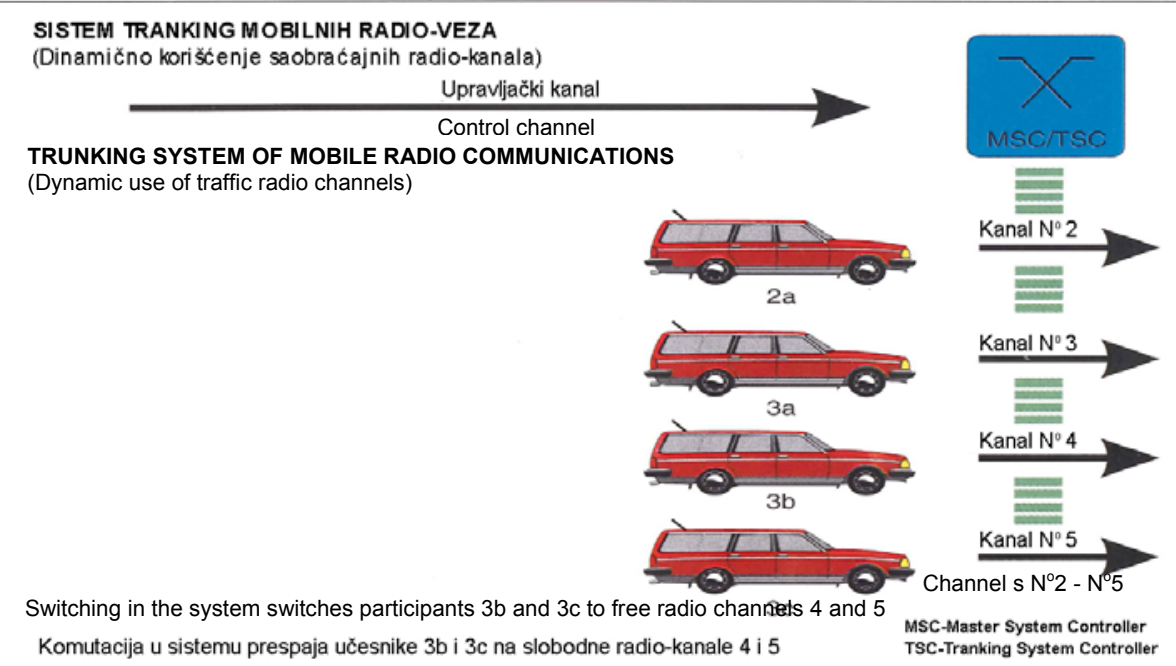

Figure 1 - Use of channels in conventional and trunking systems of mobile radio communications (Rohde \& Schwartz, 1994)

Puc. 1 - Использование каналов в обычных и транкинговых системах мобильной радиосвязи (Rohde \& Schwartz, 1994)

Слика 1 - Коришћење канала код конвенционалних и транкинг система мобилних радио-комуникација (Rohde \& Schwartz, 1994) 
Until about 20 years ago, some previously produced Analogue trunking systems of mobile radio communications were still relatively widespread in the world, such as: SMART TRUNK, then systems with the standard MPT-1327 (ACCESSNET, ACTIONET, EURONET-46-3, STANILITE, JRC, SELECTACOM MX and others), systems manufactured by Motorola (STARTSITE, SMARTNET, SMARTZONE), systems with distributed Control and management channel ( $L T R$ and MULTI-NET manufactured by FFJohnson Co and ESAS manufactured by Uniden). The technology of some of these systems, until that time, was used by the public security and security services of different countries, through their built Functional networks of analog trunking of mobile radio communications. (Svrzić \& Ćosović, 2000), (Ovchinnikov et al, 2000), (Svrzić \& Ćosović, 2002b)

However, since about 15 years ago, the standards for digital mobile radio communications has been much more widespread in the world, and therefore the circle of users of Digital trunking systems for mobile radio communications has been constantly expanding, which is explained by a number of their systemic advantages over analog trunking systems, such as:

- better spectral efficiency due to the application of complex procedures in signal modulation and low speed algorithms for conversion and digitization of speech signals,

- increased capacity and quality of connections in the system, with a reduction in noise levels, and

- equalization of the quality of voice signal transmission in all BRSt service zones, at the expense of the application of digital signals in combination with coding, which is very resistant to interference.

Compared to analog systems, Digital trunking systems of mobile radio connections, besides systemic advantages, provide a number of operational advantages due to:

- a successful implementation of the requirements for high operability and security of connections,

- the provision of wide possibilities for data signal transmission,

- a wider range of liaison services (including special services related to the realization of special needs of public safety and security services), and

- a successful realization of connections between participants from different networks. 
The requirement for high connection operability, first of all, means the minimum possible time for establishing a connection channel (access time $<300 \mathrm{~ms}$ ) for different types of connections (individual, group, with participants in telephone networks, etc.). With conventional mobile radio systems, it takes significantly longer than with analog trunking systems to establish a communication channel through which digital information is transmitted due to the time required to establish synchronization between transmitter and receiver. However, in mobile radio trunking systems, where the exchange of information is mainly done via BRSt, the connection channel establishment time (access time) in digital systems is commensurate with the access time in analogue systems. This is due to the fact that in both digital and analog trunking systems of mobile radio communications, as a rule, the Control Channel is realized on the principle of digital signals. In addition, in Digital trunking systems of mobile radio communications, it is much easier to implement different connection modes, which significantly contribute to the operability of the system, such as:

- direct connection mode-DMO between mobile participants (without using BRSt),

- open channel mode (allocation and reservation of frequency network resources for the needs of a certain group of users, so that they can further conduct conversations without any prescribed procedure, and in that sense without delay),

- emergency call mode,

- priority call mode,

- etc. (Ovchinnikov et al, 2000), (Svrzić \& Ćosović, 2002a, 2002b)

The requirement to provide wide possibilities for data signal transmission implies that Digital trunking systems of mobile radio communications are much better prepared for different modes of data signal transmission, which gives digital network owners much greater possibilities: for operational introduction of reductions from centralized databases, for transmission of necessary information including image transmission, and for the organization of centralized dispatch centers from the vehicle location system, realized on the basis of satellite radio navigation. Also, this means that in digital trunking systems, compared to analog ones, data signals (Data) are transmitted at significantly higher speeds (even several tens of times higher) (Nouri, 2016). In most digital trunking systems of mobile radio communications integrated with data transmission, the services of transmission of short messages and status messages, individual radio calls, facsimile connections, as well as access 
to fixed networks of data transmission connections, which work on the basis of TCP / IP, are the realized types of protocols. (Swan, 2015), (Svrzić, 2021)

The request for protection of connections includes the need to ensure the confidentiality of cvonversations (excluding the possibility that anyone other than the authentic user can extract information from the connection channel), as well as protection against unauthorized access to the system (excluding the possibility of entering the management system, attempts to disrupt the regularity of the system in any way, protection from "duplicates", and so on). As a rule, the basic mechanisms of connection protection are the application of encryption of transmitted information as well as the identification and authentication of users. It is quite natural that in Digital trunking systems of mobile radio communications it is much easier to achieve protection of connections than in the case of analog trunking systems. Even without the application of special measures for "locking" information, the Digital trunking system of mobile radio communications provides a certain degree of protection for conversations (analog radio receivers with search are completely unsuitable for listening to conversations in digital radio). In addition, some standards of digital trunking radio communications provide for the possibility of transit encryption of information, which allows the use of original (i.e. developed by the equipment manufacturers themselves) algorithms for encrypting speech and data. Also, Digital trunking systems of mobile radio connections provide the possibility of using different mechanisms for identification and authentication of users: different identification keys and SIM cards, complex authentication algorithms that use encryption, etc.

The requirement for a wide range of communication services implies that Digital trunking systems of mobile radio communications realize a modern level of service of participants in the radio network, which represents: possibility of automatic registration of participants, roaming, data signal protocol management, different priority call modes, call forwarding, and so on. Also, in accordance with standard network service functions, based on the specifications of public security and protection services, standard digital trunking radio links often include requirements for the existence of specific connection services: call mode that can be realized only with the permission of the system dispatcher, mode of dynamic modification of user groups, remote radio mode for remote listening, etc. 
The requirement for the possibility of interconnection implies that Digital trunking systems of mobile radio communications, which have a flexible structure of addressing users, provide ample opportunities for creating different Virtual Networks within the same system, and for organizing connections between participants of different networks when necessary. For public security and protection services, the request for providing the possibility of organizing connections of joint action of different specific units of services is especially relevant, in order to coordinate actions in emergency situations: various disasters, accident situations, terrorist acts, and the like.

Based on such requirements, in the past, international meritorious organizations and some world-famous manufacturers of telecommunications equipment have developed a number of different standards for the construction of Digital trunking systems for mobile radio communications. Some popular standards of digital trunking of mobile radio connections, which, in addition to TETRA, have gained international significance and on the basis of which Digital trunking systems of mobile radio communications have been built in several countries, are:

- EDACS, developed by Ericsson from Sweden,

- APCO-25, developed by the International Association of Official Representatives of General Security and Protection Services (APCOI),

- TETRAPOL, developed by the French manufacturer MatraCommunications,

- iDEN, developed by Motorola from the USA. (Ovchinnikov et al, 2000), (Svrzić \& Ćosović, 2002a, 2002b)

All these standards generally met (some less, some more) modern requirements for Digital trunking systems of mobile radio communications, as they allow to build networks of digital mobile radio communications of different configurations: from the simplest-single-zone networks of local importance to very complex multi-zone networks at the regional or national level. Mobile radio communication systems built on the basis of these standards provide different modes of digital transmission and switching of voice signal (individual call, group call, diffuse call, etc.) and data signal transmission (packet switching, circuit switching, short message transmission, etc.), as well as the possibility of organizing connections with other different communication systems via standardized interfaces (with the Digital Network of Integrated Services-ISDN, with the Public Telephone Network-PSTN, with the Functional Home ATC-PABX and others). Such Systems of digital trunking of mobile radio 
communications use the most modern forms for conversion and processing of analog speech signals, which then coincide with really effective methods for encoding information, used to protect against various types of interference (protective coding). All systems of the stated standards allow their users the possibility of using duplex radio connection. Also, manufacturers of radio equipment for these systems ensure their compliance with the MIL STD 810 standard for various climatic and mechanical influences. (Ovchinnikov et al, 2000), (Svrzić \& Ćosović, 2002a, 2002b)

However, it turned out that of all these standards, the TETRA (TErrestrial Trunked RAdio) Standard is the most promising, as over time it has been widely accepted by many global equipment manufacturers and users on all continents, with chances to (of course, in the field of functional mobile radio connection) possibly get closer to the success of the Global System for Mobile Communications. Although many analysts predicted that, due to the significantly faster development and implementation of public digital cellular mobile telephony via GSM compared to functional telephony via the Digital Mobile Radio Communications Trunking System (DMRTS), there will be more mass migration of connection system owners from their existing Functional Trunking system on the Public GSM, this did not happen en masse for several reasons:

- DMRTS are intended for professional use by special groups of users (closed, e.g. police, military or business systems) while GSM is a public system for personal communication.

- With DMRTS, system owners have supervision and control of the system operation at all times and in each of its parts.

- DMRTS offers more reliable communications in all conditions (especially in crisis situations), much faster connection and a large number of services.

- DMRTS can work with a larger number of radio channels and in more frequency bands than GSM.

- Although DMRTS is more expensive than GSM systems (radio terminals are especially expensive), it can also cover areas that GSM does not cover (for example: locations of transformer stations, thermal and hydro power plants, transmission lines, surface mines, construction sites of new roads and tunnels, wells, gas pipelines, oil pipelines, military training grounds, and other facilities). 
- DMRTS has a powerful dispatching system and a specially organized subsystem of automatic communication for connection with PABX as well as an output to PSTN and ISDN.

- With DMRTS, user terminals are much more robust and resistant to field work in all weather conditions, and even in natural disasters (higher "IP protection").

- DMRTS provide much better opportunities for data transfer and the organization of SCADA (Supervisory Control And Data Acquisition).

- DMRTS are designed for a strictly defined number of users, and as such, they have significant reserves of capacity for switching, transmission and management, both in terms of increased bandwidth and in terms of redundancy. This guarantees that the system is reliable and that there can be no overload in it.

To conclude, even if the TETRA Standard is developed on the basis of general technical solutions and recommendations of the GSM Standard, it differs greatly from it, as it is oriented towards the construction of such radio communication systems that efficiently and economically support the sharing of mobile radio networks of different groups of users, with a special emphasis on quality assurance of secrecy and protection of transmitted information, as well as towards work in regular and critical conditions of use. In that sense, special attention in the standard is paid to the interests of public safety and security services which often operate in accident and critical situations, and therefore have a number of special requirements. It i also important that TETRA must be an open standard, ie. that equipment from different manufacturers can be used together in one radio network (although, in practice, this is mainly limited to the use of mobile radio devices, and not different base radio stations). (Ovchinnikov et al, 2000), (Svrzić \& Ćosović, 2002a, 2002b), (123seminarsonly, 2004), (Swan, 2015)

\section{Overview of the TETRA 1 specification package}

According to the first-basic package of specifications, the TETRA 1 standard consists of two parts:

a) TETRA V + D (TETRA Voice + Data) - i.e. part of the standard for integrated speech and data transmission, and

b) TETRA PDO (TETRA Packet Data Optimized) - i.e. part of the standard that describes a special variant of the trunking system, oriented (only) to optimized data transmission. (Ovchinnikov et al, 2000), (Svrzić \& Ćosović, 2002b), (123seminarsonly, 2004), (Swan, 2015), (Svrzić, 2021) 
The TETRA 1 standard includes: Radio interface specifications, Interface specifications between TETRA network and Integrated Services Digital Network-ISDN, Interface specifications according to Public Telephone Networks-PSTN, Interface specifications according to Data Networks-PDN, Interface specifications for working with Telephone exchanges/networks of functional users-PABX, etc. Also, the TETRA 1 standard contains specifications for the description of basic and additional services, offered by mobile digital radio communication networks according to TETRA V + D or TETRA PDO, and the Interfaces of local and centralized (external) radio network management are specified.

The first document from the basic package of standards related to the TETRA 1 system was adopted by ETSI in August 1995 under the name ETS 300 391-Part 1,2,3 (Part 1:"Universal Personal Telecommunication (UPT)-Specification of the security architecture for UPT phase1"; Part 2:"Implementation Conformance Statement (ICS) proforms"; Part 3: "Conformance Test Specifications (CTS)".) (ETSI, 1995), and at the beginning of the following year other parts of the basic package of standards were published (ETSI, 1996). Most of the specification documents from that package were supplemented at the end of 1997, although (over time) those specifications were modified and supplemented several times (newer versions). The most important parts of the TETRA 1 standard have been translated into the following specifications:

- ETR 300391 TETRA V + D Design Guide (five parts, 1997/98);

- ETS 300392 TETRA V + D (sixteen parts, 1996-2000);

- ETS 300393 TETRA PDO (eleven parts, 1996-2000);

- ETS 300394 TETRA Conformance Testing (two parts, 1996-2000);

- ETS 300395 TETRA Codec (four parts, 1996-2000);

- ETS 300396 TETRA DMO (five parts, 1996-2000). (Ovchinnikov et al, 2000), (Svrzić \& Ćosović, 2002b)

The contents of the system Specifications of the TETRA 1 standard, from ETS 300392 to ETS 300 396, are shown in the following Tables 1, 2, 3,4 and 5 . 
Table 1

Таблица 1

Табела 1

\begin{tabular}{|l|l|}
\hline Part & The content \\
\hline Part 1 & General network design \\
\hline Part 2 & Air Interface (AI) \\
\hline Part 3 & Inter-working at the ISI \\
\hline Part 4 & Gateways basic operation \\
\hline Part 5 & Terminal equipment interface (TEI) \\
\hline Part 6 & Line connected stations \\
\hline Part 7 & Security \\
\hline Part 8 & Network management services \\
\hline Part 9 & $\begin{array}{l}\text { General requirements for } \\
\text { supplementary servicess }\end{array}$ \\
\hline Part 10 & Supplementary services stage 1 \\
\hline Part 11 & Supplementary services stage 2 \\
\hline Part 12 & Supplementary services stage 3 \\
\hline Part 13 & SDL model of the Air Interface (AI) \\
\hline Part 14 & PICS Proforma specification \\
\hline Part 15 & Interworking-extended operations \\
\hline Part 16 & Gateways for supplementsry services \\
\hline
\end{tabular}

Note: This specification has a variation of the radio interface $(\mathrm{Al}$, Release 2), which was published on 01.08.2016 within ETSI EN 300 392, Part 2, as version V3.8.1, and which is supplemented with ETSI TS100 392-18 - "Air interface optimized applications". Within this edition, the specifications also include parts: TS100 392-15- "TETRA frequency bands, duplex spacings and shannel numbering", TS100 392-16"Network Performance Metrics" and TS100 392-17- "TETRA V+D and DMO specifications".

One of the newer variations of this crucial specification was released in January 2019 for the TETRA 2-TEDS radio interface, under the designation ETSI TS 100 392-2 v3.9.1 Technical Specification, Part 2"Air Interface (AI)" (ETSI, 2019). 
Table 2

Таблица 2

Табела 2

\begin{tabular}{|l|l|}
\hline Part & \multicolumn{1}{|c|}{ The content } \\
\hline Part 1 & General network design \\
\hline Part 2 & Air Interface \\
\hline Part 3 & Inter-working \\
\hline Part 4 & Gateways \\
\hline Part 5 & Terminal equipment interface \\
\hline Part 6 & Line connected stations \\
\hline Part 7 & Security \\
\hline Part 8 & $\begin{array}{l}\text { Network management } \\
\text { services }\end{array}$ \\
\hline Part 9 & Performance objectives \\
\hline Part 10 & SDL model for air interface \\
\hline Part 11 & PICS Proforma \\
\hline
\end{tabular}

Table 3

Таблица 3

Табела 3

\begin{tabular}{|l|l|}
\hline Part & The content \\
\hline Part 1 & Radio conformance testing \\
\hline Part 2 & Protocol conformance testing-voice+data \\
\hline
\end{tabular}

Table 4

Таблица 4

Табела 4

\begin{tabular}{|l|l|}
\hline Part & The content \\
\hline Part 1 & General description of speech functions \\
\hline Part 2 & Codec \\
\hline Part 3 & Cpecific operational features \\
\hline Part 4 & Codec conformance testing \\
\hline
\end{tabular}

Table 5

Таблица 5

Табела 5

\begin{tabular}{|l|l|}
\hline Part & The content \\
\hline Part 1 & General network design \\
\hline Part 2 & Direct MS-MS air interface \\
\hline Part 3 & Repeater \\
\hline Part 4 & Gateway \\
\hline Part 5 & Security \\
\hline
\end{tabular}


It should be noted that the Specifications of the TETRA 1 standard underwent the greatest changes in 2006, which was conditioned by the newly adopted Standard TETRA 2-TEDS (TETRA Enhanced Data Service), when there were significant changes in the organization of the radio interface for fast transmission data-HSD (High Speed Data) and in the selection and standardization of additional "voice codecs" for speech digitization. In addition, these specifications subsequently underwent partial changes when they were implemented: the evolution of the TETRA SIM card, achieving interoperability (even "roaming") between TETRA 2 and public GSM, and the transition from 2.5G to $3 G$ network. What was important for all holders of hitherto realized systems according to the TETRA 1 standard is that the wide compatibility with the first generation of TETRA 1 devices and the full integration of their characteristics into the new generation of TETRA 2 devices is maintained. (Duncan, 2015), (Nouri, 2016), (Svrzić, 2021)

\section{Existing interfaces within the TETRA 1 framework}

The presented Specifications of the TETRA 1 standard do not set limits for the architecture of the mobile radio communication network, so, thanks to the modular principle of construction, different configurations of such radio networks can be realized, with different areas of geographical coverage by quality radio signals. In this sense, the radio networks of the TETRA 1 standard offer a distributed infrastructure for management and switching-SwMI (Swiching Menager Infrastructure), which provides fast call transfer and preservation of the system's ability to work locally, and in case of failure of certain network infrastructure elements.

The basic elements that make up each of the TETRA 1 networks are: Base transceiver radio stations (BRSt), Mobile handheld radio stations (RRSt), Mobile transport radio stations (PRSt), Fixed radio stations (FRSt), Devices for base station management (UBRSt), Switching base station radios (KBRSt), Dispatch desks (DP), and Maintenance and operation terminals (TTOE).

The functions of operational network service of participants and their intersystem coordinated work with participants in other TETRA networks, public and functional telephony networks as well as the functions of localdispatching and central network management are determined by specified interfaces, clearly shown in Figure 2. 


\section{Typical TETRA Network}

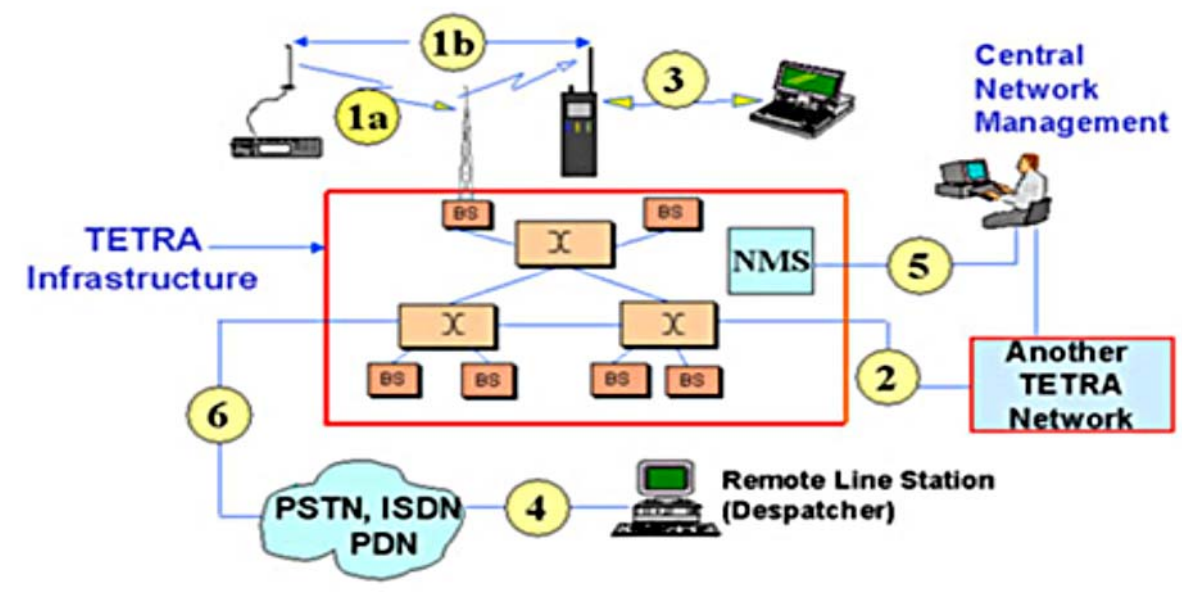

Figure 2 - Overview of different Interfaces in the TETRA standard (123seminarsonly, 2004)

Puc. 2 - Обзор различных интерфейсов в рамках стандарта TETRA (123seminarsonly, 2004)

Слика 2 - Приказ различитих интерфејса у стандарду TETRA (123seminarsonly, 2004)

The following specified interfaces can be seen in the figure:

- (1a) Radio interface for radio trunking work of BRSt (BS-Base Station) with participating mobile radio stations: RRSt and PRSt, and also with participating fixed radio stations (FRSt);

- (1b) Radio interface for direct connection between two participating mobile RSt, without participation of infrastructure network, (Direct Mode Radio Air Interface);

- (2) Inter System Interface (ISI) for the organization of connections between KBRSt (BSC-Base Station Controller) of different TETRA networks - or for connection to other TETRA networks;

- (3) Interface for connection between data transmission terminal and mobile RSt (sometimes for direct connection of local DP) -TEI (Terminal Equipment Interface);

- (4) Wired Line Interface (LSI), which connects the isolated DP to the BRSt Controller (BSC), via PSTN, ISDN or PDN; 
- (5) Network Management Interface-NMI which serves to directly connect the workstation to the Central Network Management System NMS;

- (6) Interface for connection to PABX, PSTN, ISDN (Gateways to PABX, PSTN, ISDN) and to the Package Data Network (PDN) (Gateways to PDN). (Ovchinnikov et al, 2000), (Svrzić \& Cosović, 2002b), (123seminarsonly, 2004)

Figure 3 presents the role and location of the following open interfaces: Radio-interface-AIR IF (for TMO interaction) and Radiointerface DMO (for direct connection), and Inter-system interface-ISI and Interface for connecting data transmission terminals -TEI, and within the demonstrated infrastructure of two independent TETRA networks, which basically (each of them) consist of BRSt, devices with independent switching, and KBRSt with integrated switching (Base Station, Switch, Base Station Controller).

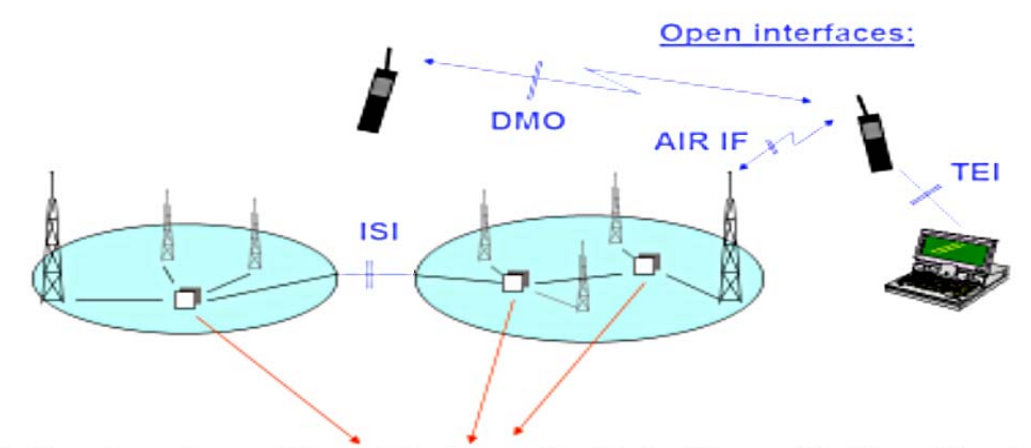

Infrastructure (Base Station, Switch, Base Station Controller etc.)

Figure 3 - Overview of the role and location of different interfaces on the TETRA network infrastructure (123seminarsonly, 2004)

Pис. 3 - Обзор роли и расположения различных интерфрейсов в сетевой инфрраструктуре TETRA (123seminarsonly, 2004)

Слика 3 - Приказ улоге и места различитих интерфејса на инфраструктури мреже TETRA (123seminarsonly, 2004)

In order to, in some special cases, increase the BRSt service area (i.e. increase the range of the connection) in the TETRA 1 standard, the possibility of using the participating mobile radio stations as a Retranslator is also provided. This is realized with the application of Direct Mode Operation (DMO), as shown in the figure. By the way, during TMO 
(Trunking Mode Operation) TETRA supports the semi-duplex mode by default, but when communicating with participants from PABX, PSTN or ISDN, it works in full time duplex-TDD (Time Division Duplex).

Namely, due to the high speed of change of the transmission and reception cycle by time multiplex, it seems that the semi-duplex mobile RSt enabled duplex communication with the participants of the mentioned telephone networks. In doing so, the TETRA 1 system supports a complex level of protection of transmitted information by encrypting speech, signaling, and user identification. In doing so, security and protection are integrated into the system and through multiple levels of identification and authentication: users by radio terminals, radio terminals by a network, one network by another network, and a user by another user. (Ovchinnikov et al, 2000), (Svrzić \& Ćosović, 2002b), (123seminarsonly, 2004)

\section{Description of the radio interface according to the TETRA 1 standard}

The radio interface, defined in the TETRA standard 1 via ETS 300 392-Part 2, is the basic interface in the system that provides for operation in a conventional frequency network with a radio channel spacing of 25 $\mathrm{kHz}$. In this case, there is a necessary, minimum duplex distance between the transmitting and receiving frequency of $10 \mathrm{MHz}$ in the radio channel. In principle, a complete frequency range of 150 to $900 \mathrm{MHz}$ can be used for TETRA standard systems, being clearly defined for use in European countries with the subbands $380-385 / 390-395 \mathrm{MHz}$ (for public safety and security services) and $410-430 / 450-470 \mathrm{MHz}$ (for service services and commercial organizations). The remaining subbands used are: $870-876 \mathrm{MHz}$, used to receive base radio stations (up-link), and 915$921 \mathrm{MHz}$, used to transmit base radio stations (down-link).

Because it was rightly expected that a large number of owners and users of Functional conventional PMR systems will directly switch to the TETRA system, i.e. to bypass the technology of Analog trunking systems of mobile radio communications (meaning PMR Standard MPT1327 and others), the use of the time division multiple access (TDMA) technique was adopted. The adopted TDMA contains four user time slots, organized on each of the $25 \mathrm{kHz}$ spaced radio carriers. So, on one pair of physical radio frequencies BRSt, (for reception- "up-link" and for transmission"dow-nlink") spaced $10 \mathrm{MHz}, 4$ independent time communication radio channels (information channels) can be organized (Figure 4). 
TETRA TDMA

- 4:1 TDMA (Time Division Multiple Access)

- $25 \mathrm{kHz}$ carrier spacing

- Digital modulation, $\pi / 4$ DQPSK at $36 \mathrm{kbits} / \mathrm{s}$

- Speech calls use one channel

- Data calls can use up to 4 channels ( Data transfer rates up to $7.2 \mathrm{kbit} / \mathrm{s}$ per channel)

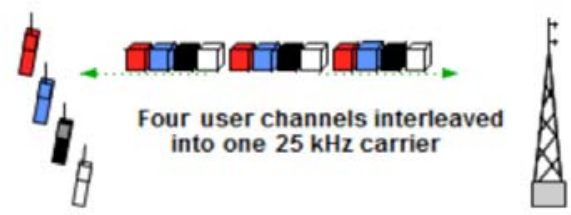

Figure 4 - Representation of TDMA, parameters and spectral efficiency in the TETRA Standard 1 (123seminarsonly, 2004)

Puc. 4 - Представление TDMA, параметров и спектральной эфффективности в рамках стандарта TETRA 1 (123seminarsonly, 2004)

Слика 4 - Приказ TDMA, параметара и спектралне ефикасности код стандарда TETRA 1 (123seminarsonly, 2004)

This way of organization maintains the same radio channel width of $25 \mathrm{kHz}$, about one radio frequency carrier, as with conventional PMR systems, but the spectral efficiency is quadrupled in relation to them, while in relation to analog trunking systems PMR ( with the MPT1327 standard, where the channel spacing is $12.5 \mathrm{kHz}$ ) it doubles. Compared to GSM, four times better spectral efficiency is also achieved, since in this system only 8 communication radio channels are organized at a width of $200 \mathrm{kHz}$, while at TETRA at a width of $200 \mathrm{kHz} 8$ radio frequency carriers are organized (with a radio-channel width of $25 \mathrm{kHz}$ ) and 4 communication radio channels on each. In addition to spectral efficiency, TETRA also provides savings in BRSt equipment, as only one transceiver radio unit is required for all four user "time slots", i.e. for four communication radio channels.

In the TETRA 1 standard, according to the hierarchy, it is defined that announcements are submitted in TDM multiframes, with a duration of $1.02 \mathrm{~s}$. By grouping 60 TDM multi frames, one TDM hyperframe is obtained. Each TDM multi-frame contains 18 TDM primary frames, of which the 18th is the Control Frame, i.e. the SACCH (Slow Associated 
Control Channel), through which signaling is always transmitted, even if all other channels occupied as working channels.

Each TDM primary frame has a duration of $56.67 \mathrm{~ms}$ and contains 4 time intervals of $14.167 \mathrm{~ms}$. In each of these time intervals, the information of one time (communication) channel is transmitted, within its duration of $14.167 \mathrm{~ms}$, by placing in the channel a channel packet of a total length of 510 bits, out of which 432 are information while the rest are "official bits". This means that within 1s, 35,999.152 bits are transmitted for all 4 communication-traffic channels, i.e. that the channel speed of the signal in one communication radio channel $=9 \mathrm{~kb} / \mathrm{s}$ (Figure 5). (Ovchinnikov et al, 2000), (Svrzić \& Ćosović, 2002b), (123seminarsonly, 2004), (Svrzić 2021)

\section{Air Interface - TDMA Illustrated}

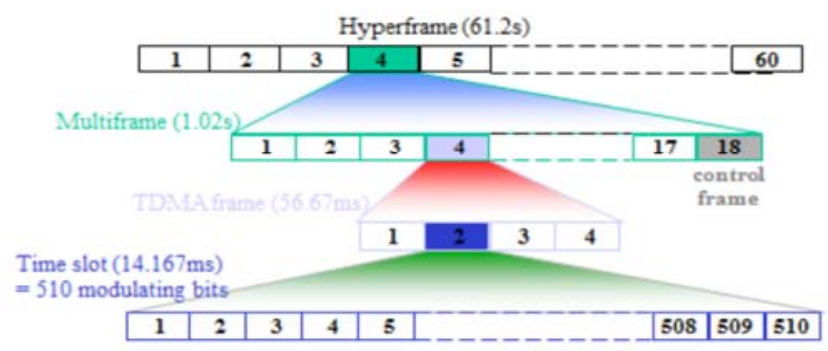

Figure 5 - Overview of the hierarchy of time structures in the TETRA system (123seminarsonly, 2004)

Puc. 5 - Обзор иерархии временных структур в системе TETRA (123seminarsonly, 2004)

Слика 5 - Приказ хијерархије временских структура у систему TETRA (123seminarsonly, 2004)

At the beginning of each channel packet, in a "time slot" of the communication radio channel, an official PA block (Power Amplifier) of 36 bits in length is handed over, intended for regulating the radiant power of the mobile radio station. It is followed by the first information block, 210 bits long, and then the SYNCA synchronization block 36 bits long, after which the second information block 216 bits long is passed. At the end of 
such a channel packet, a 6-bit protection block is passed. This protective block of bits excludes the possibility of overlapping (overflow) of information from adjacent communication radio channels.

The connection between the "time slots" in the TDM primary frame and the user communication radio channels is as follows: each time slot represents a certain period of time associated with one communication radio channel (Figure 6). It can be seen from the figure that the communication radio channel is actually a sequence of equally numbered "time slots" from continuous-successive TDM primary frames. The receiver is synchronized to a specific time slot in which it can receive and reconstruct only those messages that belong to the communication channel it is currently using (which is assigned to it for connection).

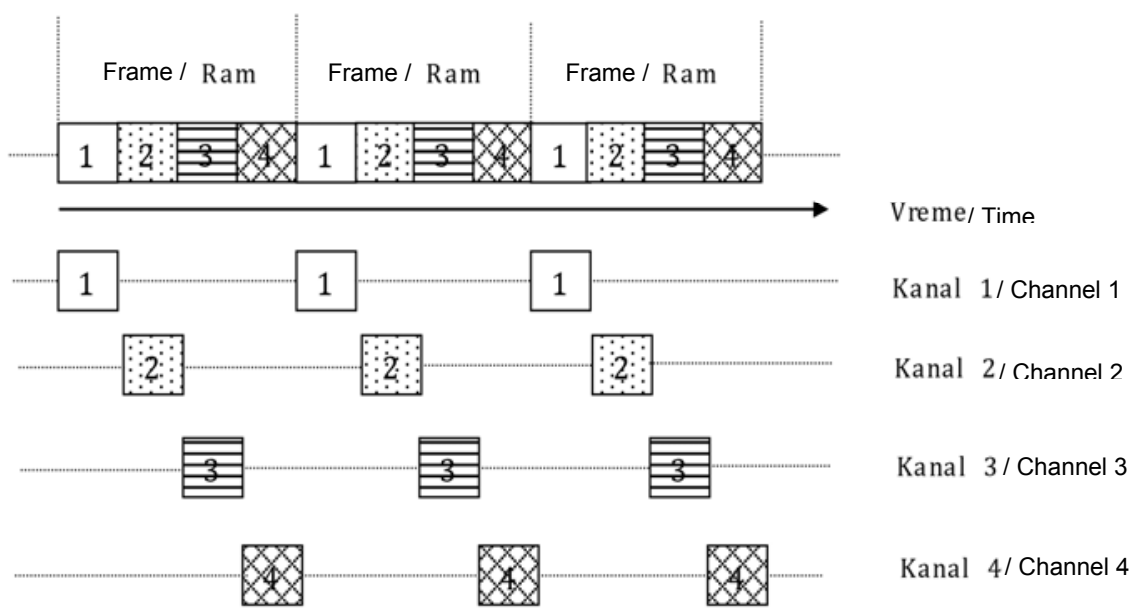

Figure 6 - Connection between time slots and communication channels in the TETRA TDM primary frame (123seminarsonly, 2004)

Puc. 6 - Связь между временными интервалами и каналами связи в первичном фррейме TETRA TDM (123seminarsonly, 2004)

Слика 6 - Приказ везе између временских слотова и комуникационих канала у примарном раму TETRA TDM (123seminarsonly, 2004)

The TETRA 1 systems use Linear differential quaternary phase modulation for modulating speech and data signals with a phase shift of $\pi / 4$, i.e. type $\pi / 4-D Q P S K$ (Differential Quadrature Phase Shift Keying), and a maximum throughput of $9 \mathrm{~kb} / \mathrm{s}$ to communication radio channel, i.e. "time slot" (which is $36 \mathrm{~kb} / \mathrm{s}$ per TDMA primary framewith on, i.e. with a symbol flow rate (dibit) of $18 \mathrm{ksymbols} / \mathrm{s}$. This then means that the 
modulation rate per one radio frequency carrier, i.e. together for all 4 radio communication channels, is $36 \mathrm{~kb} / \mathrm{s}$. (Ovchinnikov et al, 2000), (Svrzić \& Ćosović, 2002b), (123seminarsonly, 2004)

When transmitting speech signals and data signals, there is a difference in the system during their transmission since the analog speech signal is first subjected to analog/digital conversion (Figure 7).

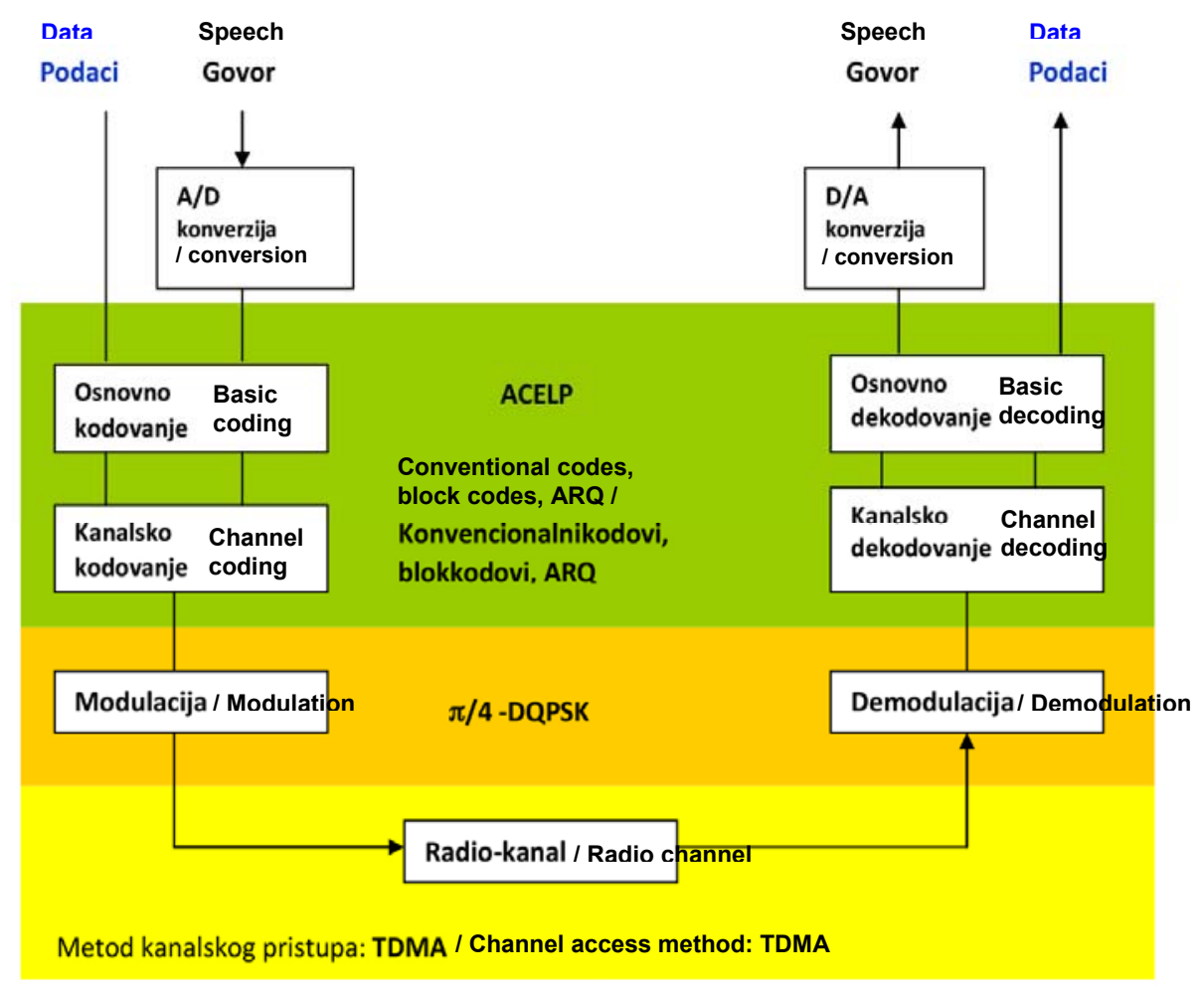

Figure 7 - Overview of the integration of speech and data transmission and signal processing in the TETRA 1 standard (Svrzić \& Ćosović, 2002b)

Рис. 7 - Обзор интеграции передачи речи и данных и обработки сигналов в рамках стандарта TETRA 1 (Svrzić \& Ćosović, 2002b)

Слика 7 - Приказ интеграције преноса говора и података и обраде сигнала код стандарда TETRA 1 (Svrzić \& Ćosović, 2002b)

After $A / D$ conversion, speech is transmitted at a bit rate of $4.8 \mathrm{~kb} / \mathrm{s}$ and encoded with a special "codec" which applies the ACELP algorithm (Adaptive Code Excited Linear Predictive) which then ensures high quality of the transmitted speech signal. The TETRA 1 system also 
transmits data signals as standard with circuit switching and packet switching. Digital data comes directly, and speech after $A / D$ conversion, to the ACELP speech codec in which they are first subjected to a protocol: basic and then channel coding ("block" and "symbolic" coding, sequence shifting and scrambling), after which interference-resistant information is formed in communication radio channels, which is further modulated by applying $\pi / 4-D Q P S K, R F$ amplified and transmitted to the air. During reception, reverse processes take place: demodulation of $R F$ signals, channel and basic decoding, and for speech signals, D/ A conversion (again, Figure 7). (Ovchinnikov et al, 2000), (Svrzić \& Ćosović, 2002b)

The bandwidth of one information-communication radio channel is standard-fixed and amounts to $7.2 \mathrm{~kb} / \mathrm{s}$, so the speed of digital information data flow can vary from $7.2-28.8 \mathrm{~kb} / \mathrm{s}$ (at the expense of combining 1-4 communication radio channels). At that, the total speed of transmission of symbols in the radio channel, at the expense of additional official information and control frame in TDM multi frame, corresponds to the modulation speed and is $36 \mathrm{~kb} / \mathrm{s}$. (Ovchinnikov et al, 2000), (Svrzić \& Ćosović, 2002b), (123seminarsonly, 2004)

\section{Organization and architecture of mobile radio networks according to the TETRA 1 standard \\ The basic concept of the organization of the use of TETRA 1 networks}

The basic commitment to the use of the TETRA system is the organization of a complex digital trunking network of mobile radio communications for several different groups of independent or partially dependent users. Users in this sense mean organizations, bodies, institutions, services, etc., which do not have their own System of functional mobile radio communications but appear as independent or partially dependent groups of participants in such a unique TETRA network. Figure 8 shows the simultaneous use of a single TETRA network for three groups of different users (police, ambulance, and firefighters). Such a unique TETRA radio network is designed as a standard to support the simultaneous work of very demanding and specific groups of users in the field of public safety and security, as well as emergency services (see the figure), and transport organizations, service organizations, and industry, local government and various services, and of course, (in specific circumstances) the military. 


\section{TETRA is the Cost - Effective Technology}

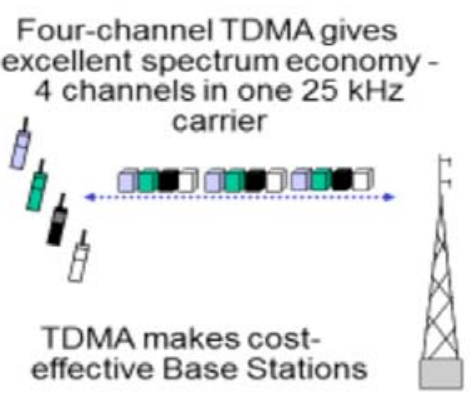
Trunking technology supports controlled use of shared

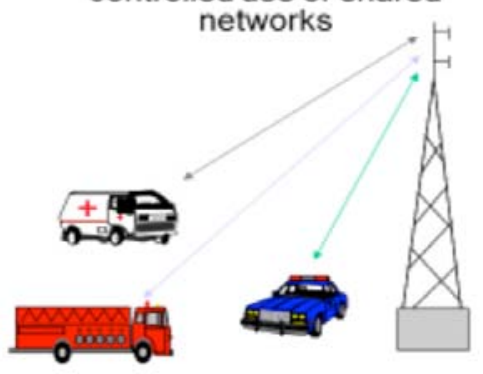

Figure 8 - Overview of simultaneous use of a unique TETRA 1 network for three different user groups (123seminarsonly, 2004)

PUc. 8 - Обзор одновременного использования единой сети TETRA 1 тремя разными группами пользователей (123seminarsonly, 2004)

Слика 8 - Приказ једновременог коришћења јединствене мреже TETRA 1 за mpu различите групе корисника (123seminarsonly, 2004)

Due to the mentioned specific characteristics, the TETRA 1 system has a multi-layered organization structure, complex protection mechanisms and very high reliability, with a great possibility of radio coverage (from some local territory to the international level). In fact, it is a concept of the organization of Virtual Networks-VNs for each group of users separately, within the whole-unique TETRA system (see Figure 9).

VNs enable the independence and autonomy of work of each of these very diverse groups of users, and at the same time, from that complex, widespread and well-organized network of UHF mobile radio communications, they all use exactly the benefits they want. That is why it is very important that in each of such VNs there is an independent Dispatching Center-DC with a Dispatcher Work Station-DWS and peripherals with great authority. 


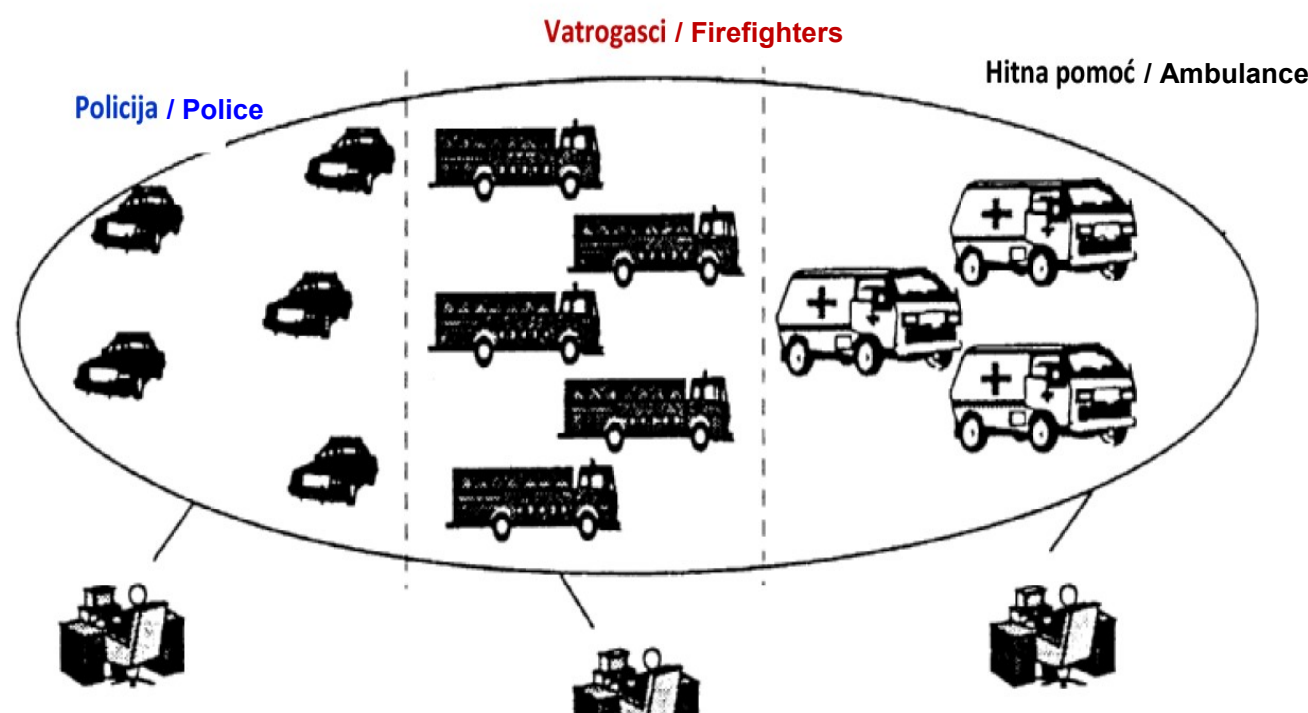

Dispečer / Dispatcher

Dispečer / Dispatcher

Dispečer / Dispatcher

Figure 9 - Overview of the organization of three virtual networks within a single TETRA 1 network (123seminarsonly, 2004)

Puc. 9 - Обзор организации трех виртуальных сетей в рамках единой сети TETRA 1 (123seminarsonly, 2004)

Слика 9 - Приказ организације три виртуелне мреже у оквиру јединствене мреже TETRA 1 (123seminarsonly, 2004)

All Dispatchers from different Virtual Networks can communicate with each other and, in case of special critical or accidental situations (major traffic accidents, fires, natural disasters), form special Temporary Functional Groups (composed of participants from their own network user groups), as well as Mixed functional groups (composed of participants from different network groups of users), depending on the given accident situation and defined tasks (Figure 10). At the same time, the participants of such new groups have the opportunity to, with the permission of the Dispatcher, change the membership of the group if necessary, so like the Dispatchers, they can belong and communicate with more groups. The work of the entire Virtual Network is usually managed by one Dispatcher, although the network (for some groups of participants) can work without the Dispatcher. From its DWS, that Dispatcher has an overview of the current position of each member of the group (knows the radio cell in which it is located) and its status. Also, he has an insight into every 
communication between the participants and can break into it, to convey a message, to interrupt it or to insert a new interlocutor. By listening to ambient noise, especially in Public security services (even in the Military), the Dispatcher can monitor the work of individuals in cars or in the field without their active participation. Multiple levels of identification and verification, as well as strict control of access and communication in the network by the Dispatcher, guarantee that only authorized users can use the system. In case of theft of a mobile radio device, the Dispatcher can remotely disable any further operation of that terminal (temporarily or permanently), as well as monitor its movement through the network.

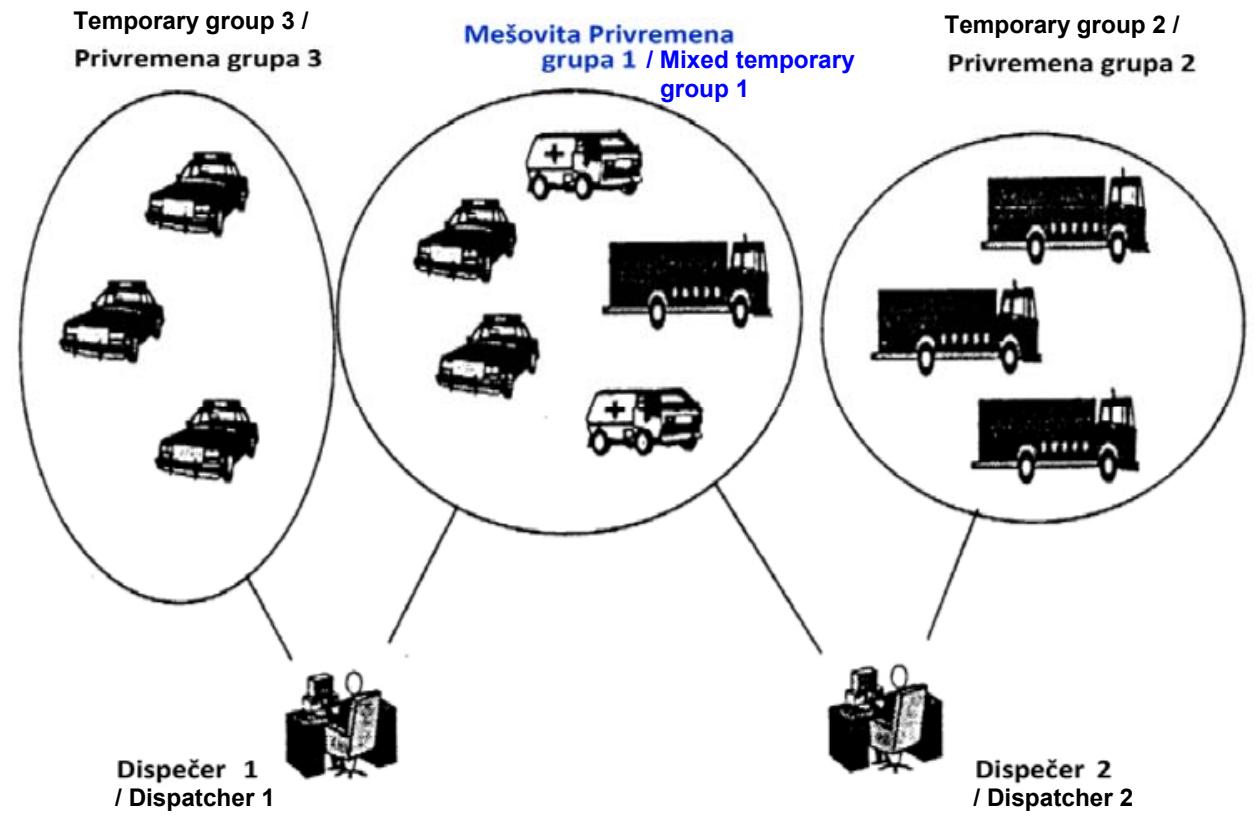

Figure 10 - Overview of the formation of a special-temporary mixed functional group of users in the event of an accident within a single TETRA 1 network (123seminarsonly, 2004)

Puс. 10 - Обзор фрормирования специально-временной смешанной фрункциональной группы пользователей при аварии в рамках единой сети TETRA 1

(123seminarsonly, 2004)

Слика 10 - Приказ формирања посебне - привремене, мешовите и функционалне групе корисника у случају акцидентне ситуације у оквиру јединствене мреже TETRA 1 (123seminarsonly, 2004) 
In a single TETRA network, in which there are Virtual Networks (or specialized organized groups), each group of users can seamlessly and efficiently implement their specific, specific requirements, such as:

- Beneficiaries from the Public Safety and Security Sector.

1. The police or customs authorities may on the spot, i.e. at any location, receive or send fingerprint recordings, various photographs, take important details during the investigation, etc.

2. Firefighters and special units for natural disasters can use Direct Mode (DMO) to cover any area with quality and record and transmit live, to their control points and dispatchers, the situation on the ground.

3. Ambulances and ambulance services can, already from their vehicles, send recordings and the first findings of the injured.

- Users from the Industry or Construction Sector can send plans, sketches and drawings to the field, isolated facilities, warehouses, and construction sites.

- Users from the Sector of Transport Organizations most often send the positions of their means of transport - buses, trucks, ships (AVLAutomatic Vehicle Location) using GPS.

- Users from the Sector of Service and Service Organizations can verify credit and bank cards in the field when charging for their services to customers. When transferring data from a bank or credit card, a transfer with a high level of protection is used. (Ovchinnikov et al, 2000), (Svrzić \& Ćosović, 2002b), (123seminarsonly, 2004)

General principle of the organization of connections of mobile participants and the basic elements of TETRA networks

For an initial understanding of the principles of connection organization, within the TETRA 1 standard Specification, ETSI EN 300 392-1 v1.4.1 (in "Annex A") from 2009, models of simplified-standard connection configurations through LMNs (Land Mobile Networks) are given, i.e. models of terrestrial mobile radio networks which consist of three basic elements:

- mobile radio stations-MS (Mobile Station);

- Swiching Manager Infrastructure-SwMl; and

- Line Stations-LS, i.e. line (wired, radio-link,...) connected stations.

Mobile radio stations are connected to the TETRA SWMI by a radio channel, while LSs are connected to this structure via wired and other communication lines. The variants of the standard configurations of connection in the network are shown in Figure $11 \mathrm{a}$ ), b) and c), where: Um - radio interface of TETRA 1 network in TMO, Ud - radio interface of 
direct connection in DMO, and TI- wired or other line connection. (Ovchinnikov et al, 2000), (Svrzić \& Ćosović, 2002b), (ETSI, 2009)

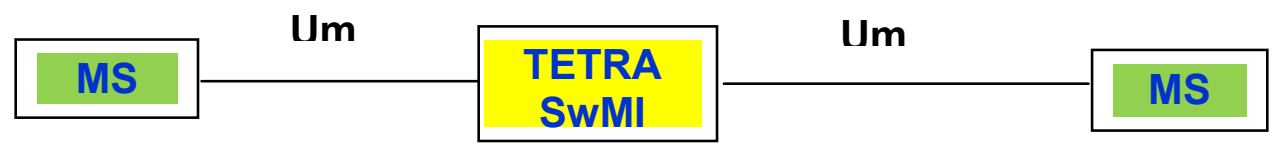

a) Connection between two mobile radio stations in the TMO mode, using SWMI

а) Связь между двумя мобильными радиостанциями в режиме TMO, при использовании SwMI

а) Веза између две мобилне радио-станице у режиму TMO, коришћењем SwMI

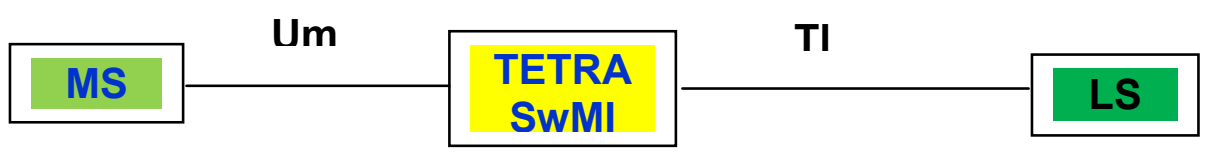

b) Connection between a mobile station and a line station in the TMO mode, using SwMI

б) Связь между мобильной станцией и линейной станцией в режиме ТМО при использовании SwMI

б) Веза између мобилне и линијске станице у режиму TMO, коришћењем SwMI

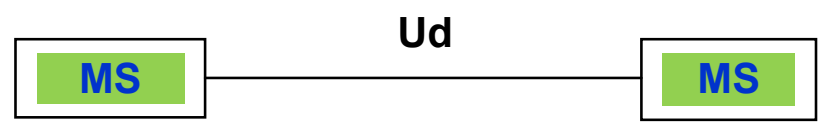

c) Connection between two mobile radio stations in the DMO mode, without the use of SwMI

в) Связь между двумя мобильными радиостанциями в режиме DMO, без использования SwMI

u) Веза између две мобилне радио-станице у режиму DMO, без коришћења SwMI

Figure 11 - Overview of the variants of the standard configurations of TETRA 1 mobile radio networks (ETSI, 2009)

Puс. 11 - Обзор вариантов стандартных конфигураций сетей мобильной радиосвязи TETRA 1 (ETSI, 2009)

Слика 11 - Приказ варијанти стандарда еталонских конфигурација мрежа мобилних радио-веза TETRA 1 (ETSI, 2009)

Functional schemes for the construction of various mobile radio networks of the TETRA 1 standard represent a set of elements of radio 
network equipment that are interconnected by certain specified interfaces. As mentioned earlier, each complete TETRA 1 radio network contains the basic equipment elements: Base Transceiver Station-BTS, Base Station Control Function-BCF, Base Station Controller radio-station-BSC, Dispatching desk-DP, Mobile: hand-held, stationary and transport radio stations, Terminal for maintenance and operation and Monitoring and Control Center.

The Base transceiver radio station-BTS is a base stationary radio station which provides participants with a connection in a specific radio cell (or radio zone) of its coverage. The BTS performs basic functions related to the transmission of radio signals: connection to mobile radio stations, link line encryption, spatially separate reception (spatial diversity), power management of mobile radio stations, and radio channel management.

The device for controlling the base radio station-BCF is an element of equipment from the BTS, which is also part of the equipment of the radio network infrastructure. It is also called Site Controller-SC and it contains a system for switching the available communication radio channels of the respective BTS, which can software-manage several other BTSs from its zone. It also provides direct or indirect access to external networks such as ISDN, PSTN, PDN, and PABX, and can also be used for line connection of Dispatching desks-DP and Terminal for maintenance and operation (TO\&M).

The Base radio station controller-BSC is an element of radio network equipment which, compared to the BCF, has greater switching and software capabilities, allowing the exchange of data between several $B C F s$. Also, like the BCF, the BSC provides direct and centralized access to external connection networks. In this sense, the BSC has an elastic modular structure and allows the use of a number of interfaces of different types. In complex TETRA radio networks, BSCs also perform the functions of connecting to other TETRA networks, as well as the functions of managing centralized databases. In such cases in the TETRA network, one of the BSCs must be declared the Main Controller of Base Radio Stations-MBSC and is specially equipped with adequate hardware and software.

The Dispatching desk-DP is a line terminal device that is primarily connected to the BSC via a wired line providing the exchange of information between the operator (Network Dispatcher) and other users in the network. It is often used for diffuse transmission of information, formation of user groups, etc, in terms of the function of Local or Central network management. 
The Mobile radio station-MS is a terminal radio station (manualportable or transport-installed in the vehicle), used by various participants in the movement, while the Stationary/Fixed radio station-FRS is a terminal radio station (a station used by participants in one stationary place (usually indoors). The Transport mobile station (built into the vehicle) is an adequate solution for working from a vehicle with a custom antenna system.

The terminal for technical maintenance and operation-TO\&M is a line terminal that is, directly or remotely, connected to the BSC or BCF, and is intended for monitoring the state of the system, performing fault diagnostics, registration of traffic information, making changes to the database of participants, etc. With the help of these terminals, the socalled function of monitoring and managing the local network LNM (Local Network Management) is often realized. (Ovchinnikov et al, 2000), (Svrzić \& Ćosović, 2002b), (123seminarsonly, 2004), (ETSI, 2009)

\section{Architecture and topology of the construction of the TETRA 1 network}

Thanks to the modular principle used in the construction of equipment, TETRA 1 mobile radio networks can be realized with architecture of different hierarchical levels and with a topology that allows different geographical coverage (from local, regional to national level), and by the type of "Star" , "Loops" or "Chains". Database management and switching functions in the TETRA 1 network are distributed, that is, they are distributed throughout the network, which ensures fast call transmission and preservation of limited working capacity of the radio network even when disconnected from some of its elements. (Ovchinnikov et al, 2000), (Svrzić \& Ćosović, 2002b)

At the national or regional level of coverage, the structure of the radio network can be realized on the basis of relatively small but complete TETRA subnets, which are connected by the Interconnection Interface-ISI, in order to realize a common - general national or regional network. In this case, a complete TETRA subnet usually means an autonomous and independent radio network which consists of all the elements of equipment listed in the previous subchapter. In such cases, it is very important that the complex architecture and topology of the TETRA network in question allow the possibility of Centralized Network Management. Namely, in such an organization, each TETRA subnet independently performs its functions of Local Control and Switching, but also provides the possibility for Centralized management from a higher 
level. The number of elements of the TETRA subnet structure depends on the type and intensity of traffic, as well as on the requirements for the level of connection efficiency. (Ovchinnikov et al, 2000), (Svrzić \& Ćosović, 2002b). A variant for building a sufficiently demanding and complex-combined configuration of a complete TETRA subnet in the TETRA 1 standard, with pronounced levels of hierarchy, is shown in Figure 12.

In the case when spare radio channels are not required, i.e. when the traffic between different BTSs is not demandingly strong and when it is mostly cell-oriented, it is possible (and sufficient) to build a TETRA subnet in a simpler "Star" configuration. Also, in the case of overlapping line-oriented paths (for example, on long conveyor routes, on railways, etc.), the TETRA subnet can be realized in the form of a very long line, i.e. "Chain of regularly connected BTSs". In this case, it is rational to provide local access to external networks via each of the Base Station Control Devices (BCF), in accordance with the required connection distance. Finally, and if conditions require so, a simple "island" type configuration of the TETRA subnet can be built, containing only one BCF and usually several BTSs.

In the radio networks of the TETRA 1 standard, various ways of ensuring the toughness of the system are provided, enabling the preservation of full or partial working capacity even in the event of failure of some of the elements from the network. It is also possible that, in the network or some part of it, there occurs a certain deterioration of one or a number of parameters, for example the time of establishing a connection, reducing the data transfer speed, etc. Therefore, for complex TETRA networks of the national coverage level, several alternative routes are used as a rule to connect with TETRA networks of the regional level. In regional TETRA networks, similar alternative routes are used to more reliably connect Base Station Controllers (BSCs). In addition, for regional networks, mutual copying of databases between different Controllers of base radio stations is envisaged (Ovchinnikov et al, 2000), (Svrzić \& Ćosović, 2002b). Similar principles have been applied in the national level and in the "Star" architecture of the TETRA 1 network of Motorola, "Dimetra IP/SR6.2", which in Serbia operates successfully for the needs of the Ministry of Interior and in which one of the users is the MoD and Serbian Armed Forces. (Krstić \& Marjanović Jakovljević, 2018), (Motorola Solutions, 2008), (Svrzić, 2021) 


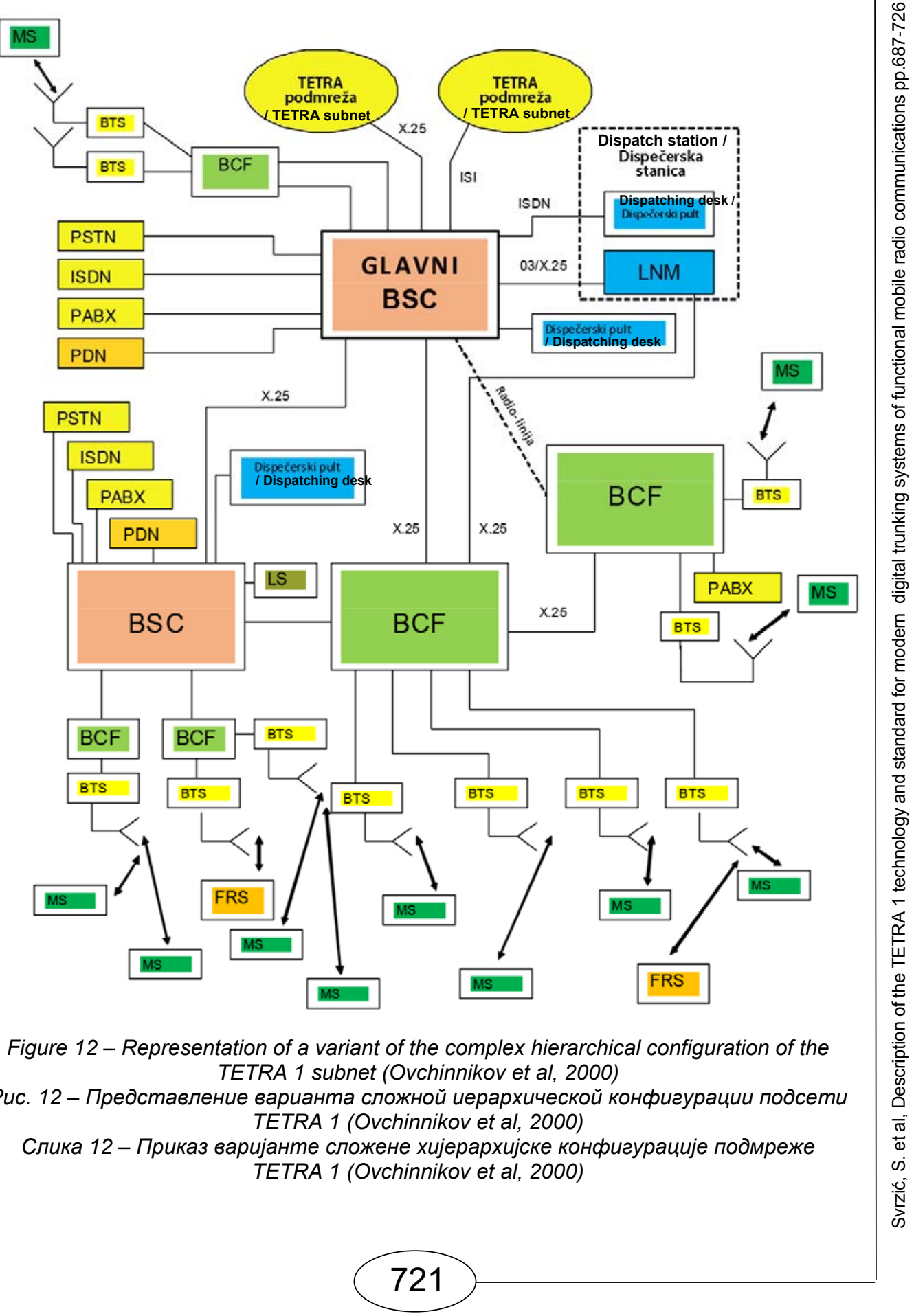




\section{Conclusion}

Due to the advantages of Digital Trunking Mobile Radio Communications Systems using the TETRA standard in relation to the Systems of analog trunking of mobile radio communications, they are today almost exclusively used for the construction of UHF systems of digital mobile radio communications of functional users. The construction and operation of these systems is defined by the basic package of TETRA 1 specifications, adopted by ETSI in late 1995 and subsequently amended in late 1977. They define all infrastructure equipment (BTS, BCF, BFC), Local Network Management-LNM and Centralized Network Management-CNM equipment and Participating Equipment (MS and LT), as well as all interfaces applied in the system. Also, they define: group, broadband and emergency calls, then fast system access ( $<300 \mathrm{~ms}$ ), TMO and DMO types of work, different levels of application of system access protection (Autentification) and information encryption, work by telephony with participants in the networks of functional PABX and public PSTN networks (including full duplex), as well as support for the smooth operation of control points (Control and Dispatch Centers), and integrated data transmission by circuit switching and independent packet data transmission by TETRA PDO. The Radio interface for TMO and DMO operating mode (according to TDMA organized) is specified in detail, both for integrated speech and data transmission-TETRA $V+D$, and for independent optimized packet mode of data signal transmission-TETRA $P D O$. Regarding the improvement of data transmission and modernization of the system to TETRA 2-TEDS, by ETSI TC (Technical Committee TETRA) and TCCE (TETRA Critical Communications Evolution), these specifications were adequately amended in 2006, and continue to be permanently revised.

During the construction of National Functional Radio Networks according to the TETRA 1 standard, special emphasis is placed on the possibility of organizing Virtual Networks, within such a complex and unique TETRA network, which can then be shared by several different users-organizations (such as police, army, firefighters and emergency services). Also, it is a great advantage for users-owners of communication systems that, within such a TETRA radio network, special-purpose functional groups of participants can be formed (permanently or temporarily), for more successful and professional execution of basic tasks, or tasks assigned to them in different accident situations. As for the type of architecture of mobile radio networks based on the TETRA 1 standard, it should be noted that it is adaptable, i.e., 
depending on their complexity, these radio networks can be built based the "Loop" topology (for complex ones), based on the topology of the "Star" (for those less complex ones) or in the form of a "Chain of linearly arranged BTSs" (to cover railways, highways, etc.). In practice, it is also possible to build small TETRA networks of the "island" type, which then usually contain the infrastructure of only one BCF and several BTSs, covering a smaller part of the territory of special interest.

\section{References}

-123seminarsonly. 2004. Seminar-Reports, Tetra Presentation [online]. Available at: http://www.123seminarsonly.com/Seminar-Reports/020/46071512Rk-6-Tetra-Presentation.pdf [Accessed: 1 February 2021].

Dunlop, J., Girma, D. \& Irvine, J. 1999. Digital Mobile Communications and the TETRA System. New York: John Wiley \& Sons, Ltd. ISBN: 0-471-98792-1.

-ETSI-European Telecommunications Standards Institute. 1995. ETS 300 391-1. Universal Personal Telecommunication (UPT); Specification of the security architecture for UPT phase 1; Part 1: Specification [online]. Available at: https://www.etsi.org/deliver/etsi_i_ets/300300_300399/30039101/01_60/ets_300 39101e01p.pdf [Accessed: 1 February 2021].

-ETSI-European Telecommunications Standards Institute. 1996. ETS 300 392-2. Radio Equipment and Systems (RES); Trans-European Trunked Radio (TETRA); Voice plus Data $(V+D)$; Part 2: Air Interface (Al) [online]. Available at: https://www.etsi.org/deliver/etsi_i_ets/300300_300399/30039202/01_60/ets_300 39202e01p.pdf [Accessed: 1 February 2021].

-ETSI-European Telecommunications Standards Institute. 2009. ETSI EN 300 392-1 V1.4.1 European Standard (Telecommunications series); Terrestrial Trunked Radio-TETRA; Voice plus Data $(V+D)$; Part 1: General nerwork desing [online]. Available https://www.etsi.org/deliver/etsi_en/300300_300399/30039201/01.04.01_60/en_ 30039201v010401p.pdf [Accessed: 1 February 2021].

-ETSI-European Telecommunications Standards Institute. 2019. ETSI TS 100 392-2 V3.9.1. Technical Specification. Terrestrial Trunked Radio (TETRA); Voice plus Data $(V+D)$; Part 2: Air Interface (Al) [online]. Available at: https://www.etsi.org/deliver/etsi_ts/100300_100399/10039202/03.09.01_60/ts_10 039202v030901p.pdf [Accessed: 1 February 2021].

Krstić, M. \& Marjanović Jakovljević, M. 2018. Primena TETRA sistema u Vojsci Srbije. In: Sinteza 2018 - International Scientific Conference on Information Technology and Data Related Research, Belgrade, pp.210-216, April 20 (in Serbian). Available at: https://doi.org/10.15308/Sinteza-2018-210-216.

-Motorola Solutions. 2008. DIMETRA TM System Documentation-Dimetra IP D6.2SR: Dimetra IP System Overview. London, UK: Motorola Solutions Ltd. 
Nouri, M. 2016. TEDS Colloquium: TETRA Enhanced Data Service (TEDS), slides 1-15 [online]. Available at: https://cupdf.com/document/tetra-enhanceddata-service-teds-5689e2a49ebfe.html [Accessed: 1 February 2021].

Ovchinnikov, A.M., Vorobev, S.V. \& Sergeev, S.I. 2000. Otkrytye standarty cifrovoj trankingovoj radiosvjazi. Moscow: MCNTI, OOO Mobilnye kommunikacii (Ser. izd. Svjaz i biznes). ISBN: 5-93184-008-7. (In the original: Овчинников, А.М., Воробьев, С.В., Сергеев, С.И. 2000. Открытые стандарты цифровой транкинговой радиосвязи. Москва: МЦНТИ, ООО "Мобильные коммуникации" (Сер. изд."Связь и бизнес"). ISBN 5-93184-008-7).

-Rohde \& Schwartz. 1994. ACCESSNET The Trunked Mobile Radio System for Professional Users [online]. Available at: https://fordonsradio.se/wpcontent/uploads/2018/01/accessnet-rs.pdf [Accessed: 1 February 2021].

Svrzić, S. 2021. 25 years of the TETRA standard and technology for contemporary digital trunking systems of professional mobile radio communications. Vojnotehnički glasnik/ Military Technical Courier, 69(2), pp.426460. Available at: https://doi.org/10.5937/vojtehg69-29340.

Svrzić, S. \& Ćosović, D. 2000. Analogni tranking sistem mobilnih radio-veza (special report - separat). Novi glasnik, 1, pp.3-18 (in Serbian).

Svrzić, S. \& Ćosović, D. 2002a. Comparative analysis of the standards for digital trunked mobile radio systems. Vojnotehnički glasnik/Military Technical Courier, 50(6), pp.567-588 (in Serbian). Available at: https://doi.org/10.5937/vojtehg0206567S.

Svrzić, S. \& Ćosović, D. 2002b. TETRA novi standard za digitalne tranking sisteme mobilnih radio-veza (special report - separat). Novi glasnik, 2-3, pp.3-36 (in Serbian).

Swan, D. 2015. 20 years of TETRA Technology. RadioResource International, quarter 2 [online]. Available at: https://radioamador.files.wordpress.com/2012/04/revista.pdf [Accessed: 1 February 2021].

ОПИСАНИЕ ТЕХНОЛОГИИ И СТАНДАРТА ТЕТRА 1 ДЛЯ СОВРЕМЕННЫХ ЦИФРОВЫХ ТРАНКИНГОВЫХ СИСТЕМ ФУНКЦИОНАЛЬНОЙ МОБИЛЬНОЙ РАДИОСВЯЗИ

Сладжан М. Сврзич ${ }^{\text {, }}$ Петар Йованоски

а ООО “Тесла системи“, г. Белград, Республика Сербия, корреспондент

${ }^{\sigma}$ EVN Macedonia, г. Скопье, Республика Северная Македония

РУБРИКА ГРНТИ: 49.00.00 СВЯЗЬ:

49.33.00 Сети и узлы связи;

49.33.29 Сети связи

ВИД СТАТЬИ: обзорная статья

Резюме:

Введение/цель: В конце 1995 года TETRA MoU уже продвигал новый стандарт TETRA в рамках ETSI, который предварительно был назван TETRA 1, и очень скоро стал использоваться, почти 
исключительно, для создания фуннциональных цифровых транкинговых систем УВЧ для мобильной радиосвязи.

Методы: $B$ данной статье описаны важные вопросы по технологии стандарта TETRA 1 и приведен анализ существующих специфрикаций с подробным представлением радиоинтерфрейса.

Результаты: В данной статье подчеркиваются многочисленные преимущества радиосистем, соответствующих стандарту TETRA по сравнению с фоункциональными системами аналогового транкинга мобильной радиосвязи, приведен обзор базового пакета спецификаций для реализации системы cоответствующей стандарту TETRA 1. В статье также описаны интерфейсы, используемые в системе, с особым акцентом на описание радиоинтерфейса, организованного по TDMA, и метод интегрированной передачи речи и данных. Представлены организация и основные элементы сетевой инфраструктуры TETRA, а также элементы оборудования конечного пользователя, в том числе приведен анализ возможных практических архитектур сетей мобильной радиосвязи, основанных на данном стандарте.

Выводы: После обобщенных описаний технологии, организации и архитектуры внимание было обращено на: основную концепцию организации использования сети TETRA 1, общий принцип организации связи мобильных пользователей и основные элементы сети TETRA, а также на архитектуру и топологию построения сети TETRA 1.

Ключевые слова: Мобильная радиосвязь-MR, профессиональная система мобильной радиосвязи-PMR, аналоговая транкинговая система, цифровая транкинговая система, TDMA, радиоэфрирный интерфеей, цифровая транкинговая система мобильной радиосвязи -TETRA, ETSI.

ОПИС ТЕХНОЛОГИЈЕ И СТАНДАРДА ТЕТRА 1 ЗА САВРЕМЕНЕ ДИГИТАЛНЕ ТРАНКИНГ СИСТЕМЕ ФУНКЦИОНАЛНИХ МОБИЛНИХ РАДИО-КОМУНИКАЦИЈА

Слађан М. Сврзић ${ }^{\mathrm{a}}$, Петар Јованоскиб

а Тесла системи д.о.о., Београд, Република Србија, аутор за преписку

${ }^{\sigma}$ EVN Macedonia, Скопље, Република Северна Македонија

ОБЛАСТ: телекомуникације

ВРСТА ЧЛАНКА: прегледни рад 
Сажетак:

Увод/циљ: Од краја 1995. године, од када је TETRA MoU у оквиру ETSI промовисао нови стандард TETRA, условно назван TETRA 1, брзо је, скоро искључиво,почео да се користи за изградњу функционалних УХФ система дигиталних транкине мобилних радио-комуникација.

Meтоде: Наведена су релевантна питања из технологије и стандарда TETRA 1 и анализиране постојеће специфрикације, уз детаљнији приказ радио-интерфрејса.

Резултати: Истичу се бројне предности које радио-системи по стандарду TETRA имају у односу на функционалне системе аналогних транкинг мобилних радио-комуникација. С тим у вези, представљен је основни пакет спецификација за реализацију система по верзији стандарда TETRA 1. Описани су интерфејси примењени у систему, са посебним освртом на радио-интерфејс, организован по TDMA, као и начин интеграције преноса говора и сигнала података. Приказана јеорганизација, као и основни елементи инфраструктуре мреже TETRA и терминалне учесничке опреме, па се анализира могућност практичних архитектура мрежа мобилних радио-комуникација по том стандарду.

Закључак: Након опитих описа технологије, организације и архитектуре, посебно су приказани: основна концепција организације употребе мрежа TETRA 1, општи принцип организације веза мобилних учесника и основни елементи мрежа TETRA, mе архитектура и топологија изградње мрежа TETRA 1.

Кључне речи: мобилне радио-комуникације - MR, фрункционалне мобилне радио-комуникације - PMR, аналогни транкинг, дигитални транкине, TDMA, радио-интерфејс, дигитални транкинг систем мобилних радио-комуникација - TETRA, ETSI.

Paper received on / Дата получения работы / Датум пријема чланка: 14.02.2021.

Manuscript corrections submitted on / Дата получения исправленной версии работы / Датум достављања исправки рукописа: 07.06.2021.

Paper accepted for publishing on / Дата окончательного согласования работы / Датум коначног прихватања чланка за објављивање: 09.06.2021.

(c) 2021 The Authors. Published by Vojnotehnički glasnik / Military Technical Courier

(www.vtg.mod.gov.rs, втг.мо.упр.срб). This article is an open access article distributed under the terms and conditions of the Creative Commons Attribution license

(http://creativecommons.org/licenses/by/3.0/rs/).

() 2021 Авторы. Опубликовано в «Военно-технический вестник / Vojnotehnički glasnik / Military Technical Courier» (www.vtg.mod.gov.rs, втг.мо.упр.срб). Данная статья в открытом доступе и распространяется в соответствии с лицензией «Creative Commons» (http://creativecommons.org/licenses/by/3.0/rs/).

(c) 2021 Аутори. Објавио Војнотехнички гласник / Vojnotehnički glasnik / Military Technical Courier (www.vtg.mod.gov.rs, втг.мо.упр.срб). Ово је чланак отвореног приступа и дистрибуира се у складу са Creative Commons licencom (http://creativecommons.org/licenses/by/3.0/rs/). 